\author{
Jerzy Sierociuk \\ Uniwersytet im. Adama Mickiewicza w Poznaniu \\ Instytut Filologii Polskiej \\ ORCID: 0000-0001-9069-6117; e-mail: jasier@amu.edu.pl
}

\title{
Wielkopolskie Słowniki Regionalne - założenia leksykograficzne serii
}

\begin{abstract}
Abstrakt: Gwary wielkopolskie są najsłabiej udokumentowane leksykograficznie, toteż proponowana seria Wielkopolskie Słowniki Regionalne jest próbą nadrobienia tych zaległości. Ze względu na ograniczoną liczebność zespołu dialektologów (tylko 3 osoby) zdecydowano, że współpracować będziemy z różnymi środowiskami lokalnymi, szczególnie ze szkołami. Eksploracja terenowa o wyraźnym założeniu leksykograficznym zawężona jest do wybranego pola tematycznego, a specjalny kwestionariusz zawiera 600-800 specjalnie skonstruowanych pytań prowokujących rozmówców do dłuższych wypowiedzi; pożądane też są fotografie omawianych desygnatów.

Identyczne tematycznie słowniki mają być przygotowane dla kilku regionów Wielkopolski - w zamierzeniu ma ich być 4-5 - co w dalszej perspektywie stwarza możliwości analiz komparatystycznych. Dopuszczamy ponadto możliwość zestawiania podobnych słowników także z różnych dialektów polskich jak i w kontekście slawistycznym.

Słowniki mają mieć charakter popularnonaukowy, przez co rezygnujemy z zamieszczania informacji gramatycznych, etymologii itp. Wartość naukową dodatkowo akcentuje obecność jednostek leksykalnych istotnych w badaniach lingwistycznych, zarówno dotyczących języka polskiego jak i niektórych zależności slawistycznych. Przestrzegana jest zasada synchronii - podajemy datę rejestracji materiału w terenie, charakterystykę współczesnego stanu gwary oraz szkic o historii terenu i współpracującej szkoły.
\end{abstract}

Słowa kluczowe: gwary Wielkopolski, leksykografia, Wielkopolskie Słowniki Regionalne.

\begin{abstract}
Greater Poland Regional Dictionaries - the lexicographic assumptions of the series. Greater Poland's dialects are among the most poorly documented with respect to lexicography. Therefore, the proposed series Greater Poland Regional Dictionaries is an attempt to make up for these drawbacks. Due to the limited size of the dialectologist team (only 3 persons), a decision was made to cooperate with various local communities, especially with schools. Field exploration with a clear lexicographic assumption is narrowed down to a selected subject field, and a special questionnaire is designed, containing 600-800 tailored questions encouraging the interlocutors to make longer statements. Photographs of these designations are equally desirable.

Thematically identical dictionaries are to be prepared for several regions of Greater Poland; the intended number is 4-5. In longer terms, it offers an opportunity of comparative analyses. It would also be possible to compile similar dictionaries of different Polish dialects as well as in the broader Slavic context. Dictionaries are in the realm of popular science; this is the reason why we decided against grammatical information, etymology, etc. The scientific value is also emphasized by the presence of lexical units important in linguistic research, both regarding the Polish language and some Slavic relations. The principle of synchrony is respected - we provide the day when the material was registered in the field, the characteristics of the contemporary dialect and brief information about the history of the area and the cooperating school.
\end{abstract}

Keywords: dialects of Greater Poland, lexicography, Greater Poland Regional Dictionaries. 
Wielkopolskie Słowniki Regionalne są odpowiedzią na powszechnie oczekiwaną - nie tylko przez środowisko dialektologiczne - leksykograficzną prezentację bogactwa gwar wielkopolskich. Od razu należy zaznaczyć, że jest to ujęcie zdecydowanie różniące się od ogłoszonej w roku 1991 propozycji Zenona Sobierajskiego, wedle którego podstawę materiałową proponowanego leksykonu miała stanowić głównie dokumentacja fonograficzna zgromadzona w ówczesnym Zakładzie Dialektologii Polskiej poszerzona o notacje ze 105 punktów badawczych do Atlasu języka i kultury ludowej Wielkopolski (AJKLW).

O podstawie materiałowej i charakterze słownika pisze:

Łącznie [...] materiały nasze możemy wyrazić liczbą przeszło 3000 stron tekstów drukowanych. Wynika z tego, że dysponujemy już rzeczywiście poważną bazą materiałową do przyszłego Stownika Ludowego Wielkopolski.

Ze względu na jakość techniczną zapisu źródeł słownik nasz można by nazwać metafonicznym. Będzie on bowiem po większej części polegać nie na zapisach bezpośrednich ze słuchu, lecz na utrwaleniach fonograficznych, czyli na nagraniach tekstów gwarowych (por. grec. meta 'według, stosownie do' i grec. fone 'głos, dźwięk') (Sobierajski 1991, 66).

Ze względu na różnice w objętości podstawy materiałowej podam za Sobierajskim, że swój projekt ogłosił, mając do dyspozycji z terenu całej Wielkopolski w sumie 153 godziny nagrań mowy ludowej (Sobierajski 1991, 65-66). Większość tych rejestracji została w różnym czasie udostępniona drukiem (Sobierajski 1985; 1990; 1995), stąd też możliwa jest ocena stopnia ich przydatności dla potrzeb leksykograficznych.

Analiza reprezentatywności materiałów wskazanych przez Sobierajskiego - pod kątem tekstowego pokrycia zjawisk językowych istotnych z punktu widzenia szkicowania charakterystyki dokumentowanych gwar - dowodzi jednak niskiego stopnia ich żywotności. Obszerny zbiór tekstów z zachodniej Wielkopolski (Sobierajski 1985) zawierający 60711 słowoform - jednoznacznie wykazuje zarówno brak wielu cech uznawanych powszechnie za definicyjne dla tych gwar (Sierociuk 2012, 2020a), jak i niewielką tekstową żywotność form deminutywnych, tak istotnych przy charakterystyce zasobu słownego gwar (Sierociuk 2018, 2020b). W jednakowym stopniu dotyczy to także innego typu jednostek słownikowych. W tej sytuacji naturalne wydaje się poszukiwanie możliwości wypełnienia obserwowanej luki powstałej na niwie leksykograficznej dokumentacji gwar wielkopolskich. Dokładne analizy dostępnej podstawy materiałowej jednoznacznie wykazują, że podejmowane tu próby muszą być poprzedzone systematycznymi eksploracjami terenowymi.

Działania zmierzające do całościowego przedstawienia słownego zasobu gwar wielkopolskich w znacznej mierze warunkowane są dotychczasowymi osiągnięciami na tej płaszczyźnie. A tu trzeba sobie jasno powiedzieć, że Wielkopolska powszechnie uznawana jest za dialekt mający najskromniejszą dokumentację leksykograficzną. Na konieczność zestawienia leksykonu reprezentującego wybrany podregion gwarowy Wielkopolski zwracali już uwagę dialektolodzy spoza środowiska poznańskiego (Reichan, Woźniak 2001, 41; Karaś 2011, 293). Warto przytoczyć tu opinię współtwórców Słownika gwar polskich PAN, którzy uważają, że 
nie wydaje się celowe opracowywanie wielkiego naukowego słownika gwarowego całego szeroko pojętego dialektu wielkopolskiego, zwłaszcza że dialekt ten dysponuje wielotomowym Atlasem języka i kultury ludowej Wielkopolski oraz spełniającą rolę atlasu pracą Henryka Nowaka Gwary poludniowej Wielkopolski.

Jeśli nie wydaje nam się celowe i widzimy duże trudności przy opracowywaniu wielkich słowników dialektów małopolskiego, mazowieckiego i wielkopolskiego, to przy tej okazji pragniemy podkreślić, że bogate materiały z wszystkich tych dialektów znajdują się w ogólnogwarowym Stowniku gwar polskich PAN opracowywanym w Krakowie.

Polska leksykografia zmierza - jak się wydaje - w kierunku opracowywania i wydawania słowników gwarowych mniejszych regionów dialektalnych (Reichan, Woźniak 1991, 40).

Z ujęć regionalnych sugerowana jest potrzeba opracowania słownika z zachodniej Wielkopolski (Reichan, Woźniak 1991, 41).

W tej sytuacji szczególnie pouczająca jest analiza zawartości kartoteki wydawanego przez krakowski zespół PAN Słownika gwar polskich (SGP). Zważywszy na to, że kartoteka krakowska gromadzi poświadczenia użyć wyrazów gwarowych także z XIX wieku, braki dokumentacji wielkopolskiej są szczególnie istotne. Fakt ten bowiem w wielu wypadkach zniekształca całościowy opis zjawisk gwarowych przygotowywany w oparciu o tęże kartotekę. Wielkopolska praktycznie jest pozbawiona bogatego wyboru tekstów gwarowych; nawet uwzględnienie trzech tomów wydanych przez Sobierajskiego nie spełnia wymogów stawianych źródłom leksykograficznym (zob. wyżej).

W wykazie źródeł (SGP 1977) podawane są informacje pozwalające nakreślić reprezentacje leksykograficzną poszczególnych rejonów; obejmują one nazwę miejscowości wraz z lokalizacją, eksploratora i rok dokonanego przezeń zapisu oraz ilość dostarczonych kartek. Podobnie postępował zespół redakcyjny, podając na początku informacje o napływających materiałach uzupełniających; od z. 16. (reorganizacja prac redakcyjnych) takich danych jesteśmy pozbawieni. Zestawiając odpowiednio te materiały, uzyskujemy obraz wielce zaskakujący. Przytoczmy wypis informacji dotyczący dokumentacji dwu powiatów, z terenu których aktualnie kończone są prace nad wydaniem stosownych słowników:

\section{POZNAŃ}

1. Krzesinki-Poznań - Adam Tomaszewski, 1930-1932, 10 k.

2. Krzyżowniki-Poznań - Adam Tomaszewski, 1930-1932, 10 k.

Poznański pow.:

3. Ceradz Kościelny - Adam Tomaszewski, 1930-1932, 10 k.

4. Cerekwica - Edmund Kownacki, 1970-1971, 600 k.

5. Chludowo - Adam Tomaszewski, 1930-1932, $10 \mathrm{k}$.

6. Kicin - Adam Tomaszewski, 1930-1932, $10 \mathrm{k}$.

7. Kiekrz - Adam Tomaszewski, 1930-1932, 10 k.

8. Komorniki - Adam Tomaszewski, 1930-1932, 10 k.

9. Konarzewo - Adam Tomaszewski, 1930-1932, $10 \mathrm{k}$.

10. Koziegłowy - Adam Tomaszewski, 1930-1932, 5 k.

11. Łagiewniki - Adam Tomaszewski, 1930-1932, $10 \mathrm{k}$. 
12. Łódź - Adam Tomaszewski, 1930-1932, 10 k.

13. Modrze - Adam Tomaszewski, 1930-1932, $10 \mathrm{k}$.

14. Mrowino - Edmund Kownacki, 1970-1971, 165 k.

15. Pobiedziska - Adam Tomaszewski, 1930-1932, $10 \mathrm{k}$.

16. Radojewo - Adam Tomaszewski, 1930-1932, $10 \mathrm{k}$.

17. Skórzewo - Adam Tomaszewski, 1930-1932, 10 k.

18. Słupia - Adam Tomaszewski, 1930-1932, $10 \mathrm{k}$.

19. Stęszew - Adam Tomaszewski, 1930-1932, 250 k.

20. Swarzędz - Adam Tomaszewski, 1930-1932, 10 k.

21. Tomice - ??? [UAM 1977']

22. Wierzenica - Adam Tomaszewski, 1930-1932, 10 k.

\section{RAWICZ}

1. Golina Wielka - ??? [AJŚrp²]

2. Grąbkowo - Władysława Stachowska-Dembecka, 1967-1972, 15 k.

3. Konary - ??? [UAM 1977]

4. Kubeczki - Władysława Stachowska-Dembecka, 1967-1972, 7 k.

5. Sowiny - ??? [2 razy UAM 1977]

6. Szkaradowo - Władysława Stachowska-Dembecka, 1967-1972, 2 k.

7. Tarchalin - Władysława Stachowska-Dembecka, 1967-1972, 30 k.

8. Zakrzewo - Władysława Stachowska-Dembecka, 1952-1954 i 1967-1972, 1900 k. (w tym też materiał do MAGP, punkt 46A)

9. Zielonawieś - ??? [AJŚrp]

Zestawienia tego typu są o tyle istotne, że poza terenową reprezentacją podstawy materiałowej przynoszą także jej charakterystykę. Należy tu zauważyć istotną właściwość przedstawionych danych; mogą one być interpretowane na dwu płaszczyznach. Z jednej strony jest to reprezentacja ,ilościowa” punktów terenowych - tu 20 miejscowości z jednego powiatu sugeruje obfitość materiału, co jednak w świetle danych ilościowych z poszczególnych miejscowości już taką wartością nie jest -10 $\mathrm{k} .(\mathrm{kartek}=$ fiszek) nie daje wglądu w zawiłości gwarowej leksyki. Z drugiej strony zaś widoczny jest całkowity brak tożsamości chronologicznej. Gwary okolic Rawicza nie mają zupełnie archiwaliów przedwojennych, wypełniających praktycznie cały zbiór z powiatu poznańskiego. Tym samym zatem prawie 40 lat odstępu czasowego w uwzględnionych rejestracjach ogranicza możliwość podejmowania analiz porównawczych.

Wprawdzie informacje te mogą być uaktualnione przechowywanymi w Pracowni Dialektologicznej UAM pozostałościami spuścizny Adama Tomaszewskiego (większość jego notatek zaginęła w czasie wojny) niemniej nie są to dane znaczące; przykładowo mamy tu: 320 fiszek z Łagiewnik (w zestawie powyższym punkt 9.), 364 fiszki z Pobiedzisk (punkt 13.), ale już z miejscowości Promno jest tych fiszek

${ }^{1}$ UAM 1977 - materiał z prac magisterskich napisanych w 1977 r. na UAM pod kierunkiem prof. dra hab. Henryka Nowaka.

${ }^{2}$ AJŚrp - materiały rękopiśmienne do Atlasu językowego Śląska (Zaręba 1969-1996). 
tylko 26. Materiały te nie wchodzą jednak do zestawu źródeł krakowskiej kartoteki SGP.

Wielkopolskie Słowniki Regionalne pomyślane są jako wyjście naprzeciw oczekiwaniom zarówno naukowym jak i popularnym. Wymóg naukowy to przede wszystkim prezentacja materiału leksykalnego gwary konkretnej okolicy oraz przestrzeganie zasady ograniczenia tematycznego wraz $\mathrm{z}$ wynikającymi $\mathrm{z}$ tego konsekwencjami. Koncepcja prezentacji leksykograficznej języka mieszkańców wsi wielkopolskiej krystalizowała się kilka lat, stąd też przedstawianie poszczególnych jej fragmentów przy różnego typu okazjach (tu przywołam kilka opracowań, ukazując jednocześnie historię przedsięwzięcia: Sierociuk 2006; 2010; 2016; Шерочук 2019). $\mathrm{Z}$ czasem prace te zaowocowały myślą przeniesienia analogicznych działań na teren szerszy, stwarzając podstawę do oglądu językowo-kulturowej wspólnoty wsi słowiańskiej (Sierociuk 2017; 2020c). Aspekt popularny proponowanego słownika przejawia się głównie nakierowaniem na wirtualnego odbiorcę, mieszkańca danej okolicy. Konsekwencją powyższego jest konstrukcja i forma samego słownika z przyjętą transkrypcją włącznie.

Zawartość poszczególnych tomów ograniczona jest zatem tematycznie ${ }^{3}$ oraz regionalnie. Granice tematyczne wynikają z chęci zaprezentowania leksyki w miarę jednorodnej, co w konsekwencji stwarza możliwości przywołania notowań ułatwiających wgląd w strukturę zależności leksykalno-semantycznych konkretnego wycinka gwarowej rzeczywistości. Jeżeli uwzględnimy ponadto, że na etapie eksploracji terenowej materiał pozyskiwany jest w oparciu o zestaw konkretnych zagadnień (szczególny rodzaj „kwestionariusza” ograniczonego tematycznie) stanowiących podstawę w miarę luźnej rozmowy (ale jednorodnej tematycznie) to uzyskujemy możliwość notowania jednostek, które przy odpytywaniu z tradycyjnego kwestionariusza by się nie pojawiły chociażby z tego powodu, że są to jednostki albo rzadko używane, albo wcześniej nie były eksploratorowi znane. Innymi słowy taki leksykon, gromadząc w rzeczywistości materiał ograniczony tematycznie, zastępuje niewielkie fragmenty słownika ogólnodialektalnego, przynosząc jednocześnie materiał „gęsty” w kontekście relacji leksykalnosemantycznych. Zestawiony wedle omawianych tu zasad słownik ukazuje leksykę bardzo ograniczonego obszaru. Jego wartość - zwłaszcza naukowa - wzrasta w momencie pojawienia się analogicznego, zestawianego wedle tych samych założeń, dokumentującego bogactwo gwarowej leksyki innego terenu.

Dodajmy, że możliwość takiej konfrontacji legła właśnie między innymi u podstaw ograniczenia terenowego. Ponadto słownik przynoszący leksykę niewielkiego regionu cieszy się większym zainteresowaniem społeczności lokalnej, poszukującej w nim elementów albo sobie znanych, albo „używanych w naszej okolicy”. To założenie przyczyniające się do popularyzacji lokalnego języka (gwary) i kultury ludowej w znacznym stopniu przesądza też o nadaniu tym słownikom charakteru prezentacji w znacznym stopniu popularnej.

3 W wyjątkowych sytuacjach dopuszczamy także przygotowanie słowników bardziej ogólnych, obejmujących kilka pól tematycznych. Dotyczy to głównie miejscowości o gwarach szczególnie istotnych dla charakterystyki dialektalnej regionu. 
Z powyższego wynika, że opracowywane przez nas słowniki jako jednostki wydawnicze lokalizują się - także z założenia - w zestawie słowników małych. Będą się one mieściły w grupie - wedle propozycji klasyfikacyjnej Kazimierza Woźniaka - zawierającej do 3000 jednostek leksykalnych (Woźniak 2000, 32), z założenia też nie przekraczając kolejnej bariery 10000 haseł. Jeżeli jednak będziemy mieli na uwadze fakt, że ma być to ujęcie przynoszące jedynie określony wycinek ograniczonej terytorialnie gwary to w dalszej perspektywie - poprzez swoiste ,uzupełnianie tematyczne" - możliwe jest konstruowanie bogatej reprezentacji słownictwa dokumentowanej gwary. Uprzedzając dalsze kwestie, podam tu przykładowo słowniki opracowywane we współautorstwie przez Justynę Kobus, skupiające się na gwarach okolic Gniezna (Kobus, Gniazdowski 2018; Kobus, Stępień 2018; Kobus, Migdałek 2021). Swoistym kontekstem jest tu słownik języka mieszkańców ziemi łukowskiej (Sierociuk 2019a) pozwalający wskazywać osobliwości leksykalne gwar uwzględnionych obszarów.

Te - w sumie niewielkie - słowniki z założenia mają tworzyć siatkę ,„punktów badawczych". Zakładamy bowiem, że identyczne tematycznie leksykony będą opracowane dla czterech-pięciu zespołów gwar wielkopolskich. W zamierzeniu naszym jest więc przygotowanie w jednakowym wymiarze słowników ukazujących gwary Wielkopolski wschodniej i zachodniej, a także północnej i południowej; oczekiwane będą też ujęcia słownictwa Wielkopolski środkowej. W miarę możliwości będzie to dążenie do „pokrycia” siecią takich słowników całego regionu.

Ograniczenie objętości słowników warunkowane jest zakładanym ich popularnonaukowym charakterem, szczególnie chęcią pobudzenia zainteresowania lokalną gwarą i kulturą. Zważywszy na to, że lokalny odbiorca preferuje książki niewielkich objętości kosztem wydań wielotomowych, zdecydowaliśmy się między innymi na powyższe rozwiązanie. Dodatkowo musiał być brany pod uwagę koszt - stosunkowo niska, przystępna cena nie zniechęca do nabycia.

Obecnie panuje duże zapotrzebowanie na tego typu słowniki w związku z zainteresowaniem kulturą poszczególnych regionów. Staną się one przydatne w nauczaniu szkolnym. Powstanie tego typu dzieł zależy w znacznej mierze od inicjatywy i prężności lokalnych ośrodków interesujących się kulturą regionu. Miłośnicy swych rodzinnych okolic odegrają tu rolę decydującą (Reichan, Woźniak 1991, 41).

Poszerzenie grupy eksploratorów terenowych możliwe staje się w momencie podjęcia współpracy z lokalną społecznością; najczęściej jest to niewielka grupa uczniów lokalnej szkoły. Nad przebiegiem działań środowiska szkolnego czuwa zasadniczo nauczyciel (najczęściej polonista) grupujący osoby zainteresowane oraz będący upoważnionym przedstawicielem środowiska akademickiego. Całość przedsięwzięć podejmowanych w szkole poprzedzona jest warsztatami dialektologicznymi prowadzonymi dla zainteresowanych przez przedstawiciela Pracowni Dialektologicznej UAM, który nota bene - będąc organizatorem realizowanego przedsięwzięcia jest też następnie (współ)redaktorem powstającego słownika. Przeprowadzane w szkole warsztaty wyjaśniają uczniom główne założenia projektu oraz sposoby jego realizacji. $\mathrm{Na}$ tym etapie przekazywana jest uczestnikom podstawowa wiedza o specyfice lokalnej gwary, 
objaśniana jest zasadność i postać pytań będących podstawą pozyskiwania materiału w terenie.

Przygotowany przez zespół Pracowni Dialektologicznej UAM kwestionariusz zawiera średnio 600-700 pytań koncentrujących się wokół nadrzędnego pola tematycznego. Zważywszy na ewentualną uciążliwość badań oraz przyzwyczajenie uczniów do określonej czasowo koncentracji młodego eksploratora całość kwestionariusza podzielona jest na partie zawierające zazwyczaj do 100 pytań. W praktyce przynosi to około 0,5 godziny rozmowy. Wszystkie partie kwestionariusza są obowiązkowo nagrywane; do tego też praktycznie sprowadza się rola uczniów, którzy pozyskane materiały przekazują koordynatorowi szkolnemu. Całość rejestracji terenowych - także dokumentacja fotograficzna - jest z kolei przekazywana drogą mailową do właściwego opracowania leksykograficznego.

Podział kwestionariusza na mniejsze partie dyktowany jest tym, że nie wszyscy członkowie grupy dialektologicznej mogą (z różnych powodów) odpytać wszystkie fragmenty. Ponieważ na niewielkim obszarze badawczym aktywnych jest kilkoro uczniów, staramy się żeby w miarę możliwości - niekoniecznie przez jedną osobę odpytane były wszystkie fragmenty.

Poszczególne partie kwestionariusza koncentrują się tym samym na wybranych partiach tematyki nadrzędnej. Dla tematu Praca na roli $i$ w gospodarstwie są to: Nawożenie, orka, bronowanie; Siew, sianokosy, torf; Żniwa i omłot; Praca przy koniach; Praca przy świniach, drobiu, itp. Niektórym pytaniom towarzyszy rysunek konkretnego przedmiotu (np. kosy, cepów czy wozu) z oznaczeniem istotnych części składowych, które należy nazwać. Ponieważ zazwyczaj nagrania poszczególnych partii prowadzone są w kilkudniowych odstępach, umożliwia to swobodne wprowadzenie powtórzeń pytań o leksemy istotne z punktu widzenia charakterystyki leksykalnej (czy gramatycznej) dokumentowanej gwary.

Kwestionariusz zazwyczaj kończy zestaw pytań pogrupowanych w Varia, dzięki którym chcemy uzyskać terenowe potwierdzenie zjawisk niekoniecznie powiązanych tematycznie. To tutaj głównie będą pojawiały się pytania pozwalające ustalić stopień żywotności wybranych leksemów lub form (np. topól/topola, reduplikacja - $n$ w odmateriałowych przymiotnikach typu drewnianny, glinianny, szklanny). W tym miejscu zazwyczaj są też pytania o zjawiska istotne przy podejmowaniu zagadnień dotyczących historii (i rozwoju) języka (np. -ev-/-ov-: 'miejsce w stodole, gdzie można wjechać wozem': bojewicalbojowica, bojewisko/bojowisko, klepisko) czy też relacji ogólnosłowiańskich (np. bystry 'jasny’: bystre słońce, bystra sukienka). Są to jednostki leksykalne, które w odczuciu odbiorców słownika nie zakłócają jego (za)wartości, odnotowując materiał istotny z punktu dociekań badawczych podnoszą jego przydatność naukową.

Założeniem jest, żeby każde ujęcie zawierało podstawowe informacje o regionie jak i przybliżało środowisko współpracującej szkoły. W wielu wypadkach właśnie informacje tego typu są szczególnie cenione przez lokalnych odbiorców. Jako „nasza książka”, „nasz słownik” w zauważalnym stopniu wpływa na podniesienie stopnia identyfikacji ze swoim regionem; zauważane są - i doceniane - lokalne formy językowe oraz przejawy lokalnej kultury ludowej - bo przecież to ,,jest w książce”. Starsze pokolenie niejednokrotnie wyraża też aprobatę dla podejmowania tego typu 
przedsięwzięć. Przejawem jednoznacznej oceny są fragmenty dwu wypowiedzi stanowiących swoiste motto jednego ze słowników:

niedtugo młodzież pozapomina jak wyglon dała kosa ... jak wyglondały grabie ... jak widty ... $i$ do czego to jest ... o! ...

dobrze że ten wywiad prowadzisz ... troszke młodziiż si dowie ... (Sierociuk 2019a, 5).

Przedstawione zestawienia ukazujące podstawę materiałową zgromadzoną w kartotece SGP, a pochodzącą z dwu powiatów wielkopolskich (nie jest to zresztą sytuacja wyjątkowa), oraz konfrontacja tegoż ze wspomnianymi rejestracjami Sobierajskiego jednoznacznie przekonują, że podjęcie próby opracowania jakiegokolwiek słownika gwarowego Wielkopolski musiało być poprzedzone gruntowną eksploracją terenową, i to eksploracją zdecydowanie nakierowaną na pozyskiwanie materiałów z wyraźnym przeznaczeniem leksykograficznym.

Wstępne badania prowadzone m.in. w Bukówcu Górnym koło Leszna jednoznacznie dowodziły dynamicznych zmian zachodzących nie tylko w strukturze leksykalnej mowy ludności zamieszkującej te tereny. Analogiczne procesy obserwowałem i na innych obszarach. Powtórzone po 40. latach badania na terenie ziemi łukowskiej jednoznacznie dowodzą wypadnięcia z użycia czepigi 'rączki pługa' (Sierociuk 2019a, 42). W tej sytuacji naturalne wydawało się ograniczenie przedziału czasowego uwzględnianego materiału. Chcieliśmy uniknąć sytuacji, że słowniki nasze będą objaśniały znaczenia wyrazów dawno już nieużywanych w lokalnych gwarach. Jako przykład niech posłuży dokumentacja hasła bamber w SGP, gdzie jednorazowe potwierdzenie dwu znaczeń ('duże, bulwiaste ziemniaki', 'duży, nieruchawy wół’) zostały zarejestrowane przez Oskara Kolberga w roku 1875 (Sierociuk 2019b).

Przygotowywane słowniki prezentują materiał współczesny; ten aspekt wyraźnie podkreśla każdorazowo wskazywany czas prowadzonych eksploracji. Chcemy bowiem, żeby prezentowany zbiór - poza podstawą porównania - umożliwiał w przyszłości śledzenie procesów rozwojowych języka mieszkańców Wielkopolski (i nie tylko).

Ze względu na wielość haseł - jak już zaznaczyłem - są to słowniki małe, niejako z założenia przynoszące dokumentację mniej niż 3000 leksemów. Ten „uszczerbek” rekompensowany jest jednak bogatą ilustracją tekstową haseł oraz ich „gęstością” dyktowaną zawężonymi granicami uwzględnianego pola tematycznego.

W zależności od konkretnego tematu przewodniego materiał przynoszący podstawę słownika pozyskiwany jest drogą zadania od 550 do około 1000 pytań. Wzrost liczby kwestii podejmowanych w trakcie eksploracji terenowej powodowany jest „odkrywaniem" nowych, nieznanych do tej pory elementów leksykalnych, które pojawiły się w trakcie prac przygotowawczych do wcześniejszych przedsięwzięć. Dobrze ilustrują to poniższe przykłady, gdzie w jednym wypadku przy serii pytań dotyczących budowy miotły pojawia się roślina haza, w wypadku drugim hyćka jako rodzaj potrawy wypłynęła przy dociekaniach sprawdzających zasięgi szczegółowej semantyki hyćki w znaczeniu 'krzew czarnego bzu' i 'owoce czarnego bzu'. Nazwa haza, zważywszy na teren rejestracji - południowa Wielkopolska, niedaleko od Rawicza - może być uwzględniana przy próbach ustalenia etymologii nazwy etnicznej Chazy/Hazy (i określenie: gwary chazackie). 


\section{A jak robiono miotly?}

no to byty ... oj! ... takie gatonzki ... obciente też ... czasem z brzozy ... bo brzoza takie cienkie ... wiotkie gałonzki ma ... albo tag na rowie rosła taka roślina ... co sie nazywata haza ... ona teraz też rośnie jeszcze ... żólto kwitnie tak ... z tej hazy ... albo jeszcze ... no może z tej wikliny to może mniej ... ale ... też z takich jakiś cieńszych prentów z dżewa (!) ... z jakiegoś krzewu ... czy z czegoś ... (Czekanów, gm. i pow. Ostrów Wlkp.; nagranie z 2017 r., inf. ur. 1935 r.).

Jak mówią na rodzaj dzikiego bzu o białych kwiatach i czarnych owocach, robią $\mathrm{z}$ niego herbatki?

bez ... czarny bez ... a jeszcze mówióm na to hyćka ... moge powiedzić o hyćce? ... hyć$k a$... zaraz pani powiem jak to była hyćka ... ja gotuje kapuste z kaszom ... i my mówimy na to hyćka ... mój zieńć przyjechot (!) ... no i byt obiad akurat ... i hyćka była ... i mówi do mnie ... tak se myśli ... mówi ... z hyćki chce obiad robić? ... ja postawiłam ... i on do mnie mówi że hyćka to oni mówiom na czarny bez ... a my hyćka na kapuste z kaszom ... (Kopanina, gm. Damasławek, pow. Wągrowiec; nagranie z 2016 r., inf. ur. 1940 r.).

Oba interesujące tu nas określenia nie pojawiają się w dotychczasowych ujęciach leksykograficznych, toteż chęć sprawdzenia ich terenowej żywotności wydaje się ze wszech miar uzasadniona.

Konfrontacja danych charakteryzujących podstawę materiałową słowników wielkopolskich z analogicznymi wypisami ze źródeł SGP - nawet z materiałami Sobierajskiego - jednoznacznie wypada na korzyść naszych leksykonów.

Reprezentujący powiat poznański Słownik języka mieszkańców okolic Pobiedzisk (Kobus, Migdałek 2021) zawiera ponad 1900 haseł (plus 80 fotografii) reprezentujących odpowiedzi na 976 pytań. Rozmowy z 16 informatorami z 9 miejscowości zlokalizowanych w granicach jednej gminy obejmują nieco ponad 20 godzin nagrań. Podobnie jak i przy opracowywaniu innych słowników eksploracje terenowe prowadzone były także przez pracowników naukowych UAM.

Aktualnie - mimo trudności spowodowanych sytuacją pandemiczną - pozyskiwane są materiały mające być podstawą leksykonu gromadzącego słownictwo dotyczące świata dziecka. Uczniowie zlokalizowanej na terenie Chazów (zespół kilku wsi koło Rawicza w południowej Wielkopolsce) szkole w Zielonej Wsi nagrywają rozmowy z mieszkańcami 4 okolicznych miejscowości. Przy eksploracji zaangażowanych jest 9 osób mających do dyspozycji 820 pytań pogrupowanych w 8 działach. Przekazane już do Pracowni Dialektologicznej UAM nagrania pozwalają szacować, że odpytanie każdego kwestionariusza przyniesie 2,0-2,5 godziny nagrań wypowiedzi mieszkańców tejże okolicy. Po uspokojeniu sytuacji epidemicznej nagrania uzupełniające - podobnie jak w sytuacji każdego z innych przedsięwzięć - przeprowadzą członkowie akademickiego zespołu dialektologicznego. Tym sposobem materiał zawarty na stronach słownika będzie obejmował do 20 godzin nagrań wypowiedzi respondentów. Obecnie jeszcze trudno dokładnie określić liczebność haseł, niemniej jednak nie będzie to w znaczącym stopniu odbiegało od zawartości innych słowników serii.

Nieco większy obszar objęty został badaniami przez zespół uczniów I LO w Łukowie. Słownik języka mieszkańców ziemi tukowskiej (Sierociuk 2019a) jest jednym 
z pierwszych opracowań serii; wprawdzie oparty jest na mniejszym zestawie pytań (594) lecz punkty badawcze (25 miejscowości) rozlokowane są w granicach prawie całego powiatu. Większy obszar objęty eksploracją pozwolił pozyskać materiał prezentujący nieco ponad 1400 haseł (plus 82 fotografie w części słownikowej). W sumie zarejestrowanych zostało nieco ponad 28 godzin nagrań.

Cała dokumentacja drogą mailową przekazywana jest do Pracowni Dialektologicznej UAM, gdzie jedna osoba - zasadniczo jest to (współ)redaktor tomu - dokonuje transkrypcji. Zabieg ten gwarantuje jednolitość rozstrzygnięć/zapisów ewentualnych kwestii szczegółowych. Tym sposobem unikamy wariantywności na etapie transkrypcji, a zamieszczony w słowniku materiał (zwłaszcza cytaty użycia) daje gwarancję tożsamej interpretacji zjawisk fonetycznych. Przyjęty dla potrzeb słowników zapis wypowiedzi rozmówców odbiega od tradycyjnie stosowanego w badaniach dialektologicznych zapisu fonetycznego; warunkowane jest to nastawieniem na osoby zainteresowane leksyką gwarową lub też kulturą ludową regionu, które w tej sytuacji zazwyczaj mają ograniczone możliwości korzystania $\mathrm{z}$ tego typu opracowań.

Podejmowaniu się opracowania każdego słownika przyświeca założenie, że będzie on dostępny dla szerokiego kręgu odbiorców, tym samym będzie się przyczyniał do popularyzacji języka i kultury regionu. Żeby zatem nie interesował tylko wąskiego grona dialektologów (ze względu na zapis fonetyczny) należało opracować system łączący dotychczasowe przyzwyczajenia ortograficzne czytelników z możliwością przekazania najważniejszych cech gwarowych. Zaproponowana transkrypcja uproszczona (pośrednia) respektuje najważniejsze zasady ortografii języka polskiego (która i tak jest po części konwencjonalna: dwuznaki $s z, c z, d \dot{z}$ oznaczają pojedyncze, samodzielne głoski, nie zaś połączenie głosek typu $s-z, c-z, d-\dot{z}$ ). Uwzględniająca historyczne uwarunkowania ortografia polska ma przecież typ książka, który to wyraz niezależnie od wykształcenia osoby mówiącej jest realizowany jako $k s i o^{n} s z k a$ - czyli nie ma tu nosowego a (jest przecież „ogonek” jak przy $e$ - a więc: gęś), brak też dźwięcznego $\dot{z}$ (przed bezdźwięcznym $k$ ). Żeby nie wprowadzać potrzeby uczenia się przez czytelnika wielu reguł nowej ortografii wprowadzamy zasadę, że w takich sytuacjach - chodzi o prawidła wymowy polskiej - proponowana ortografia jest tylko w niewielkim (w miarę w najmniejszym) stopniu jej modyfikacją.

Przyzwyczajenie ortograficzne czytelnika szczególnie zauważane będzie przy zapisie dwu cech gwarowych: nosówek oraz istotnej dla gwar Wielkopolski i Małopolski realizacji tzw. fonetyki międzywyrazowej. W pierwszym wypadku chodzi głownie o realizację typu gasi, gdzie tradycyjny zapis $a$ odpowiada $o$ nosowemu. W sytuacji drugiej będzie to odstępstwo od ortograficznego przyzwyczajenia typu brat matki, nasz ojciec.

Nadrzędną zasadą jest $\mathrm{w}$ tej sytuacji stosowanie dwuznaku $\mathrm{z}$ drugim elementem nosowym ( $n$ lub $m$ ) w tzw. indeksie górnym; zatem zapisujemy $g a^{n} s i$ (ale i $g y^{n} s i$ ), $s o^{n}$ siek i $s o^{m}$ siek. Asynchroniczna wymowa wygłosowych nosówek ma zgodnie z powyższym postać typu: $\mathrm{chco}^{m}$, ido ${ }^{m}$.

Fonetyka międzywyrazowa - zjawisko polegające na udźwięcznianiu wygłosu pod wpływem nagłosowej samogłoski lub spółgłoski półotwartej wyrazu następnego - daje zapis typu: brad matki, narz ojciec. 
Ponadto:

- wymowa gwarowa, dając się zapisać znakami ortografii literackiej, jest tak utrwalana, np. chtóry, nicht, śpiklerz, wierzk - przy czym podstawowe zasady ortografii ogólnej są respektowane (dotyczy to zapisu ó oraz $r z$ );

- grupy spółgłoskowe w wyrazach typu trzeba są właśnie tak zapisywane, gdyż w gwarach i w polszczyźnie literackiej są one wymawiane tak samo: czszeba;

- dwuznak $r z$ należy czytać zgodnie z zasadami ogólnymi - zatem rzeka; w jednakowym stopniu dotyczy to typu zmarzly - rozdzielne wypowiadanie każdej z głosek jest w zapisie sygnalizowane znakiem - (dywizem), np. dzier-zak;

- nie stosuje się delimitacji tekstu poprzez zastosowanie wielkiej litery i kropki, wyodrębniając zdania lub inne całostki syntaktyczne; znak ... (wielokropek) sygnalizuje pauzę w wypowiedzi informatora; oddając jednocześnie sposób (także tempo) mowy stwarza tym samym podstawę do podjęcia analiz składniowych (chodzi także o tzw. małą składnię, składnię grup wyrazowych oddzielonych takimi pauzami);

- znak (!) pojawia się w sytuacjach, kiedy należało rozwiać wątpliwości dotyczące wymowy konkretnego wyrazu - dotyczy to tak samo specyficznych form gwarowych, jak i realizacji „literackich” przy częściej notowanych osobliwościach regionalnych - najogólniej rzecz ujmując znak ten sygnalizuje, że zapis proponowany nie jest wynikiem błędnego odsłuchu przy transkrypcji lub ,pomyłki” komputera przy składzie tekstu.

Wszystkie wypowiedzi informatorów zapisywane są kursywą; normalną czcionką podawane są kwestie eksploratora (np. zadawane pytania) lub też szczególne „dopiski” redaktora umożliwiające prawidłowe rozumienie konkretnego fragmentu tekstu (umieszczone w nawiasach kwadratowych: [ ]).

Hasła słownikowe zgodnie z praktyką leksykograficzną podawane są w tzw. formie podstawowej (lub: słownikowej), czyli mianowniku liczby pojedynczej (rzeczowniki i przymiotniki) lub jako bezokolicznik (czasowniki). Ze względu na wirtualnego odbiorcę (spoza środowiska językoznawczego) za zbyt obciążające uznajemy podawanie $\mathrm{w}$ definicji informacji stricte gramatyczne. W słownikach tych nie ma zatem charakterystyki rodzajowej definiowanych leksemów, informacji etymologicznej itp.

W budowie hasła słownikowego wykorzystywane są trzy rodzaje czcionki:

- bold - stosowany jest jedynie w zapisie haseł; ta czcionka pojawia się w trzech miejscach: hasło; będący częścią definicji wyraz w odpowiednim miejscu objaśniony jako hasło słownika; na końcu hasła (po zapisie zob.) przynosząc wyrazy o identycznym lub podobnym znaczeniu;

- kursywa - wykorzystywana jest jedynie przy zapisie tekstu będącego fragmentem wypowiedzi rozmówcy;

- czcionką normalną zapisywane są wszelkie informacje od autora słownika, a więc: definicje hasła oraz ewentualne uzupełnienia ułatwiające zrozumienie tekstu - te pojawiające się w cytacie użycia wyrazu dopowiedzenia umieszczane są w nawiasach kwadratowych []; na końcu cytatu umieszczony jest skrót nazwy miejscowości, w której został on zarejestrowany, niekiedy użycie konkretnego wyrazu ilustrowane jest dwoma (lub więcej) cytatami z jednej miejscowości - wówczas są one oddzielane średnikiem;. 
Przywołajmy kilka przykładów zaczerpniętych ze Słownika mieszkańców ziemi łukowskiej (Sierociuk 2019a):

belka - 'część grabi, w której są zęby'; grabie ... z zembamy ... belka z zembamy (!) ... o tak; nawierca otwory $w$ belce ... whija sie ze $e^{m} b y$... oszczy sie ... równa ... to sie nazywa belka z tymi ... z zembamy ... a tu ... do tego sie wierci otwory na grabie ... i sie obsadza ... na grabisko ... (Bur); mówitam przed chwilo ... belka ... (Fik, Osn, Wks); belka ... i ... i ze $e^{m-}$ by ... (Wks); zemby ... belka ... (WDm); belka z ze $e^{m}$ bami ... (Żył); zob. beleczka, kłódka;

grono - 'tu: luźno ukształtowany rodzaj kłosa': owies ma grono ... grono sie nazywato... (Grd); [proso] w gronach ... (Brz); [proso] takie ma ... grono takie ...(Chr).

W sytuacji, kiedy definiowane wyrazy przynależą do odmiennych kręgów tematycznych podajemy je jako kolejne hasła, sygnalizując to odpowiednio cyframi rzymskimi:

ladować I - 'naprawiać, reperować'; kowal kosy kut ... plugi ładowat ... pienty ... przyktadnie przykroncat (!)... (Bur);

ladować II - 'nakładać'; nakładano ... najpierw oczywiście ono musiało być ... [...] a potem ładowato sie na wóz ... tak czen sto sie mówi ... że tadowato sie siano ... podawat te siano widłami do góry ... na wóz ... widly i grabie byly tutaj potrzebne ... (WOk).

W szczególnych wypadkach integralną częścią definicji słownikowej jest „tu:” Stosujemy je w sytuacji, kiedy znaczenie definiowanego wyrazu dokumentuje swoiste przesunięcie semantyki poza znaczenie niejako podstawowe języka opisywanej społeczności lub spotykane zasadniczo w obrębie innego pola tematycznego. Wobec sygnalizowanego cyframi innego znaczenia (niejako podstawowego - zob. wyżej: I, II.), owe „tu:” podkreśla swoiste osobliwości. Należy uwzględniać zależność, że słownik rejestrując ograniczoną tematycznie leksykę niewielkiego obszaru, w znacznym stopniu odnotowuje właśnie znaczenia sygnalizowanych owym „tu:”.

hak - 'tu: narzędzie o dwu zębach używane do ściągania gnoju z wozu': kociuba ... albo hak ... (Goł); zob. kociuba, kopacz, kopoc, kopocz, kopyrsak, kopyrtacz, korpys, korpysz, kóciuba, pazury I, szarpak.

jarzmo - 'tu: ogrodzenie dla rodzącej lub karmiącej maciory zabezpieczające młode przed zaduszeniem': jarzmo ... ewentualnie kojec porodowy ... (Goł); zob. kojec, kotnik, prosientnik.

kamienica - 'tu: stos kamieni na polu lub przy drodze': usktadany stos ... kamienica ... (Alk); to sie nazywało kamienica ... (Fik); to u nas to sie mówiło kamienica ... (WKs); zob. kamionka I.

mleko - 'tu: biała ciecz z ziarna zboża niedojrzałego jeszcze do koszenia': zboże musi

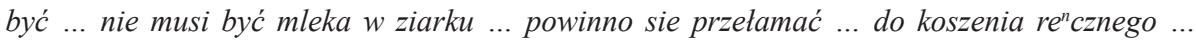
bo do koszenia teraz to musi być dobrze suche ... (Bur). 
Niekiedy zachodziła konieczność usunięcia z wypowiedzi fragmentu mało istotnego dla określenia znaczenia ilustrowanego wyrazu; sytuacje takie tradycyjnie zaznaczane są wielokropkiem ujętym w nawiasy kwadratowe: [...]. W sytuacji, kiedy teren eksploracji był znaczny, każdy z przywołanych cytatów ilustrujących użycie wyrazu hasłowego opatrzony jest informacją geograficzną, będącą skrótem nazwy miejscowości, w której został zarejestrowany. W sytuacji, kiedy tych informacji występuje kilka po sobie (bez cytatu), są one oddzielone średnikiem.

Ograniczenie dla słownika pola tematycznego jako zakresu badawczego leksyki nie powinno przesądzać o objętości zaprezentowanego materiału; jest to wypełniane zawartością ilustracji kontekstowego użycia uwzględnionych przykładów. Przypomnę, że eksploracja terenowa prowadzona jest $\mathrm{z}$ wyraźnym założeniem wykorzystania pozyskanych wypowiedzi właśnie jako tekstowej ilustracji konkretnych haseł. Obfitość - ale i objętość - przywoływanych cytatów rekompensuje liczebność haseł. Rozbudowany pod tym względem artykuł słownikowy powinien przynosić użycie specyficznych form danego hasła bądź też pośrednio informacje gramatyczne. Przykładowo można podać cytaty z rozmowy o weselu zarejestrowane w Dąbrówce Wlkp. w roku 2006:

grać - 'wydobywać melodię z konkretnego instrumentu'; musimy grać ...; grocze ... no ... tyn graje na tym ... a tyn graje na tym ...;

zagrać - 'wydobyć melodię z konkretnego instrumentu'; zagrajim ... abo tyż tak ... zagrajim $t^{u} o^{e}$... no ... Wicek! ... grómy ... no ale $c^{u} o^{e}$ ? ... no trzeciego ... już by wiedzieli co to

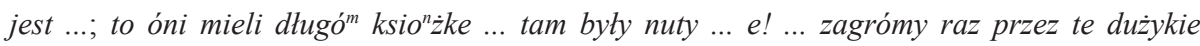
ksión $\dot{z} k i$...;

Zważywszy na to, że o ostatecznym zestawie oraz o zawartości haseł w słowniku decyduje dialektolog (pracownik naukowy), ich ilustracja tekstowa może zawierać różnego typu dane poszukiwane przez lingwistów. Niekiedy są to zamieszczane informacje o terenowej żywotności form istotnych przy opisie zjawisk z nimi niejako powiązanych. Dla niewtajemniczonego czytelnika hasło ręcznie może być uznane za mało ciekawe, tożsame z polszczyzną ogólną. Informacja o jego wyłącznym używaniu okazuje się istotna $\mathrm{w}$ kontekście podejmowanej próby wykreślenia granicy zasięgu typu ręczno. W gwarach Wielkopolski te dwie formy wykazują odmienne obszary występowania; por.:

no bo kiedyś bardzo oszczendzali pranie ... cza było ry"cznie prać ... (Dąbrówka Wlkp., gm. Zbąszynek, pow. Świebodzin, nagranie z 2012 r., inf. ur. 1942 r.);

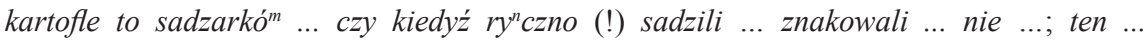
znacznik ... nie ... to ry ryno sobie w ogródku przyciongnie ... i zaśs sobie kobita sadzi ... czy kwiaty ... czy ... czy tam ... marchew ... czy coś sieje ... nie ... (Adamów, gm. Golina, pow. Konin; nagranie z 2005 r., inf. ur. 1928 r.).

Stosowanie bogatej ilustracji tekstowej umożliwia zawarcie w słowniku wielu informacji istotnych także przy szkicowaniu charakterystyki lingwistycznej dokumentowanej 
gwary. To właśnie w dłuższych cytatach można zamieszczać zauważane przez respondentów informacje o zmianach zachodzących w tejże gwarze, jak też i o leksemach (czy o innych zjawiskach językowych) dla niej obcych. Szczególnych przykładów dostarczają badania prowadzone na pograniczach dialektalnych czy też językowych. Poniższe ilustracje rejestrowane były w Dąbrówce Wlkp., miejscowości do 1945 r. pozostającej poza granicą Polski:

jak pokosili to późnij ustawili gromodki ... dzie ińdzi mówiom myndele ... nie ... a u noz mówili grómodki ...;

to jes kwoka od kurczont ... kluka ... no ... to sie mówi kluka ... ona klukata (!) ... nie kwokała tylko tyż klukała ...;

wie pan co to jes lunt? ... na kiebase mówili ... jak kiebasy buty takie ... nie ... to mówili ... nie ... taki kawot luńta ... na kiebase ... to nie mówili pento ... jak tero sie mówi ... nie ... tylko mówili kawot luńta ... no ...;

pioski ... kidyśs (!) ... no ... tero mówio ${ }^{m}$ żḋory ... i różnie ... nie ... ale przód to mówili ... " 0 ... na tych pioskach to nidz bardzo nie urośnie ...;

pin $^{n}$ dziesio ${ }^{n} t$ kila jes cyntner ... ale to jeszcze $w$ Nimczech dzisia (!) majóm ${ }^{\prime}$... centnery ... funty ... metry po wojnie przyszly ... bo jeszcze my sie z tego nawet śmiali ... bo jag ludzie zza Buga przyszli oni liczyli na metry ... a my mówili se ... no przeeż na metry to sie liczy materiat ... a nie cienżary jakieś ... nie ... to my sie jeszcze śmiali z tego ... to wim że to przyszo po wojnie ... bo my (!) kiedyś ni ... metry to my ni mówili ... na to metry ... a cyntnery $i$ funty ...

Dwa pierwsze cytaty jednoznacznie rozstrzygają żywotność leksemu na innych terenach wchodzącego w relacje synonimiczne (grómodka-mendel); kolejne trzy dokumentują zmiany zachodzące w tej gwarze. We wszystkich wypadkach są to informacje podawane przy okazji ilustrowania żywotności leksemu uznawanego za typowy dla gwary dąbrowieckiej.

Uzupełnieniem hasła tekstowego bywa fotografia przedstawiająca definiowany desygnat. Ponieważ ilustracje te dostarczają także uczniowie biorący udział w eksploracjach, ich jakość - i dokładność - nie we wszystkich wypadkach spełnia wymogi umożliwiające pełne wykorzystanie ich w publikacji. Tak jak warstwa materiałowa uzupełniana jest przez (współ)redaktora całości, takoż i bywa z dokumentacją fotograficzną. Zaangażowanie zespołu dialektologicznego w ostateczny kształt (i zawartość) leksykonu przesądza, że w znacznym stopniu są to ilustracje o dużej wartości dla dociekań etnograficznych. Widoczne to jest zwłaszcza w zestawianiu fotograficznej dokumentacji do słowników reprezentujących tereny znacznie oddalone. Dobrym przykładem jest tu demonstracja sprawdzania poprawności osadzenia kosy stosowana w okolicach Łukowa (południowe Mazowsze) i w Węglewie (środkowa Wielkopolska):

Wielkopolskie Słowniki Regionalne są pomyślane jako leksykony popularnonaukowe, o których kreśląc perspektywy polskiej leksykografii gwarowej, Reichan i Woźniak w roku 1991 pisali między innymi:

Obecnie panuje duże zapotrzebowanie na tego typu słowniki w związku z zainteresowaniem kulturą poszczególnych regionów. Staną się one przydatne w nauczaniu szkolnym. Po- 


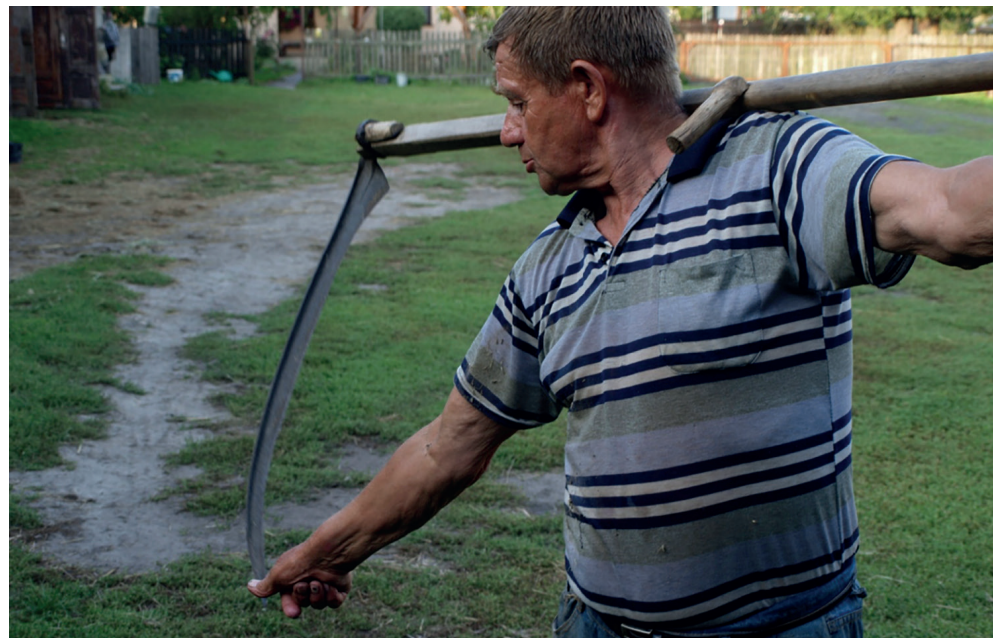

Fot. 1. Kośnik sprawdza osadzenie kosy (okolice Łukowa; fot. J. Sierociuk [2019])

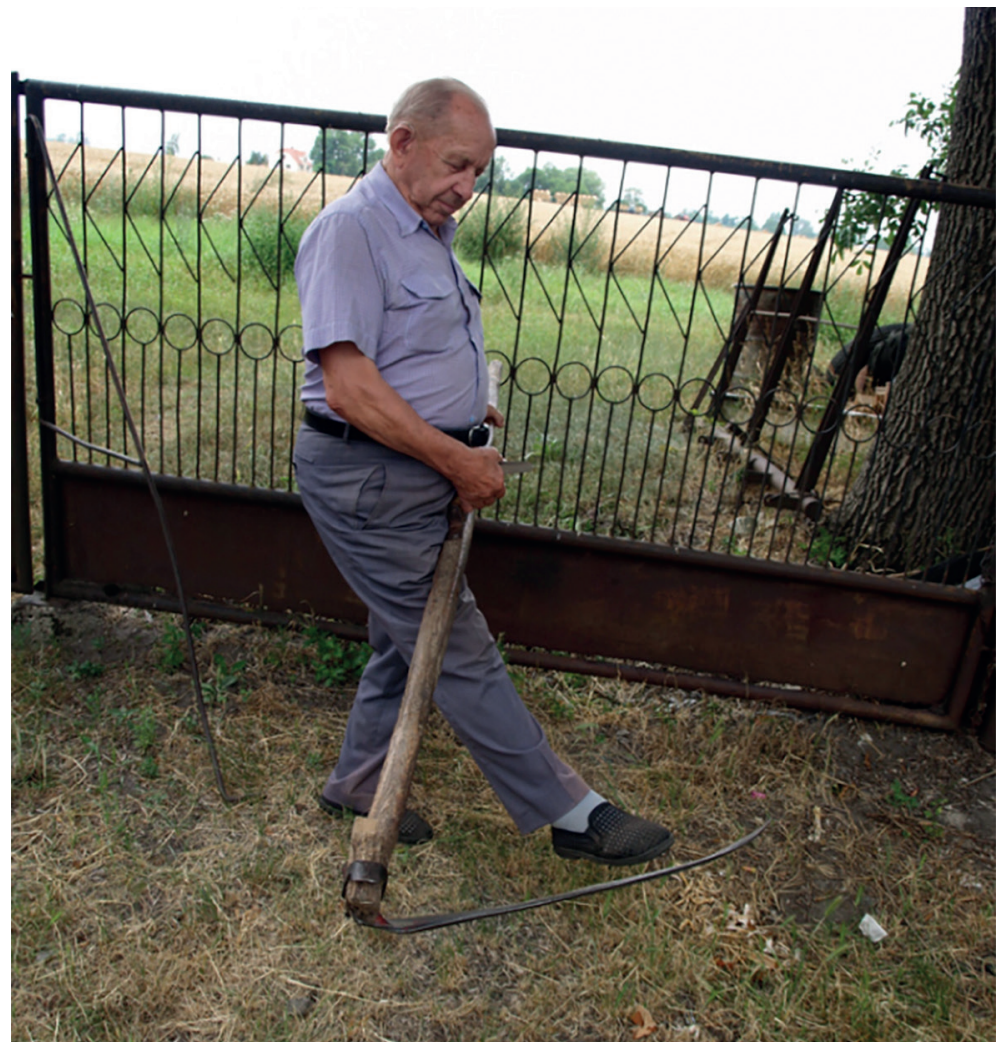

Fot. 2. Kośnik sprawdza osadzenie kosy (Węglewo; fot. J. Sierociuk) 
wstanie tego typu dzieł zależy w znacznej mierze od inicjatywy i prężności lokalnych ośrodków interesujących się kulturą regionu. Miłośnicy swych rodzinnych okolic odegrają tu rolę decydującą (Reichan, Woźniak 1991: 41).

Do powyższych uwag warto dodać jeszcze jedną, wykraczającą nieco poza obręb gwar jednego dialektu. Tym bowiem sposobem zestawienie wedle powyższych założeń leksykonu dokumentującego zasób słownikowy gwar odmiennych kompleksów dialektalnych stwarza podstawy do podejmowania różnego typu analiz komparatystycznych. Wedle tych samych przesłanek możliwa jest także prezentacja bogactwa leksykalnego gwar pokrewnych języków słowiańskich.

\section{Wielkopolskie Słowniki Regionalne}

Kobus J., Gniazdowski T. (red.) (2018), Słownik języka mieszkańców okolic Gniezna. Święta, wierzenia i przesądy. Poznań. http://psp.amu.edu.pl/asset/public/1411/Slownik_Gniezna.pdf

Kobus J., Stępień M. (red.) (2018), Słownik języka mieszkańców okolic Czerniejewa. Praca na roli $i w$ gospodarstwie, Poznań. http://psp.amu.edu.pl/asset/public/1412/Slownik_Czerniejewa.pdf

Kobus J., Migdałek A. (red.) (2021), Słownik języka mieszkańców okolic Pobiedzisk. Praca na roli $i$ w gospodarstwie. Poznań.

Osowski B. (red.) (2018a), Gospodarz. Słownik języka mieszkańców powiatu kolskiego, Poznań. https:/wydawnictwo.ptpn.poznan.pl/wp-content/uploads/2021/02/Gospodarz.-Slownik-jezyka -mieszkancow-powiatu-kolskiego.pdf

Osowski B. (red.) (2018b), Gospodyni. Słownik języka mieszkańców powiatu kolskiego, Poznań. https://wydawnictwo.ptpn.poznan.pl/wp-content/uploads/2021/02/Gospodyni.-Slownik-jezyka -mieszkancow-powiatu-kolskiego.pdf

Osowski B. (red.) (2019), W kuchni u pleszewian. Stownik języka i kultury mieszkańców powiatu pleszewskiego, Poznań. https://wydawnictwo.ptpn.poznan.pl/wp-content/uploads/2021/02/ W-kuchni-u-pleszewian.-Slownik-jezyka-i-kultury-mieszkancow-powiatu-pleszewskiego.pdf

Sierociuk J. (red.) (2019a), Słownik języka mieszkańców ziemi łukowskiej. Praca na roli i w gospodarstwie, Poznań. http://psp.amu.edu.pl/asset/public/1413/Slownik_ziemi_lukowskiej.pdf

\section{Literatura}

Karaś H. (2011), Polska leksykografia gwarowa, Warszawa.

Reichan J., Woźniak K. (2001), Perspektywy polskiej leksykografii gwarowej, [w:] Gwary Dziś, t. 1. Metodologia badań, red. J. Sierociuk, Poznań, s. 33-42.

SGP, Stownik gwar polskich, oprac. Zakład Dialektologii Polskiej Instytutu Języka Polskiego PAN, t. I, z. 1: A-Algiera, Wrocław-Warszawa-Kraków-Gdańsk-Lódź 1979 - t. X. z. 33: I-Iżyna, Kraków 2019.

SGP (1977), Słownik gwar polskich, oprac. Zakład Dialektologii Polskiej Instytutu Języka Polskiego PAN, Źródta, Wrocław-Warszawa-Kraków-Gdańsk.

Sierociuk J. (2006), Regionalny stownik gwarowy - nowa propozycja z udziatem środowiska lokalnego, [w:] Język - literatura - wychowanie. Praca zbiorowa dedykowana Profesor Annie Kowalskiej, red. J. Bałachowicz, S. Frycie, Warszawa, s. 65-70. 
Sierociuk J. (2010), Założenia metodologiczne regionalnych słowników gwarowych powstających przy współudziale środowisk lokalnych, Studia Dialektologiczne, t. IV, red. H. Kurek, A. Tyrpa, J. Wronicz, Kraków, s. 135-143.

Sierociuk J. (2012), Cechy definicyjne gwar w języku mieszkańców wsi, [w:] Językoznawstwo. Prace na XV Międzynarodowy Kongres Slawistów w Mińsku 2013, t. I, Z Polskich Studiów Slawistycznych, seria XII, Warszawa, s. 159-166.

Sierociuk J. (2016), Słowniki regionalne jako wstępny etap opracowania Stownika ogólnowielkopolskiego, [w:] Stowiańskie stowiki gwarowe - tradycja i nowatorstwo, red. D.K. Rembiszewska, Warszawa-Lomża, s. 245-254.

Sierociuk J. (2017), Językowo-kulturowa wspólnota wsi słowiańskiej - założenia projektu badawczego, „Gwary Dziś”, t. 9, s. 71-83, http://gwary.ptpn.poznan.pl/wp-content/uploads/2019/ 12/Gwary-9-06-Sierociuk.pdf.

Sierociuk J. (2018), Deminutiva gwarowe w systemie i w tekście, [w:] Językoznawstwo. Prace na XVI Międzynarodowy Kongres Slawistów w Belgradzie 2018, t. II, Z Polskich Studiów Slawistycznych, seria 13, red. Z. Greń, Poznań, s. 273-282.

Sierociuk J. (2019), Bamber - rozwój znaczeniowy wyrazu, [w:] „Kronika Miasta Poznania” 2: Bambrzy, s. 41-54.

Sierociuk J. (2020a), Features defining dialects spoken in language of villagers. „Gwary Dziś / Dialects Today", t. 13, s. 173-181, http://gwary.ptpn.poznan.pl/wp-content/uploads/2021/01/12 Gwary_13_2020_Features-defining-dialects.pdf; https://pressto.amu.edu.pl/index.php/gd/issue/ view/1760.

Sierociuk J. (2020b), Dialectal diminutives in a system and a text, „Gwary Dziś / Dialects Today", t. 13, s. 191-200, http://gwary.ptpn.poznan.pl/wp-content/uploads/2021/01/14_Gwary_13_2020_Dialectal-diminutives.pdf; https://pressto.amu.edu.pl/index.php/gd/issue/ view/1760.

Sierociuk J. (2020c), The linguistic and cultural community of a Slavic village: research project assumptions, „Gwary Dziś / Dialects Today”, t. 13, s. 227-241, http:/gwary.ptpn.poznan.pl/ wp-content/uploads/2021/01/17_Gwary_13_2020_The-linguistic-and-cultural-community.pdf; https://pressto.amu.edu.pl/index.php/gd/issue/view/1760.

Sobierajski Z. (1985), Teksty gwarowe z zachodniej Wielkopolski, Wrocław-Warszawa-KrakówGdańsk-Łódź.

Sobierajski Z. (1990), Teksty gwarowe z pótnocnej Wielkopolski, Wrocław-Warszawa-Kraków.

Sobierajski Z. (1991), Podstawowe założenia metodyczne Słownika Ludowego Wielkopolski, „Prace Filologiczne”, t. XXXVI, s. 65-77.

Sobierajski Z. (1995), Teksty gwarowe ze środkowej Wielkopolski, Poznań.

Woźniak K. (2000), Stan polskiej leksykografii gwarowej pod koniec XX wieku, [w:] Stowiańskie stowniki gwarowe, red. H. Popowska-Taborska, Warszawa, s. 17-51.

Zaręba A. (1969-1996), Atlas językowy Śląska, t. I-VIII, Warszawa-Kraków.

Шерочук Й. [Serochuk Ĭ. (Sierociuk J.)] (2019), Диалектният речник като проявление на опазването на народната култура [Dialektniiat rechnik kato prôiavlenie na opazvaneto na narodnata kultura], „Български език” [„Bŭlgarski ezik”] 66, № 3, s. 65-76. http://www. balgarskiezik.eu/3-2019/06-Sierociuk_str.\%2065-76.pdf. 